American Journal of Animal and Veterinary Sciences 5 (2): 76-85, 2010

ISSN 1557-4555

(C) 2010 Science Publications

\title{
Effects of Flavomycin on Ruminal Fermentation, In Situ Degradability and In Vivo Digestibility in Bovine Fed Sugarcane Diets
}

\author{
${ }^{1}$ S.M. Mogentale, ${ }^{1}$ E.J.A. Silva, ${ }^{2}$ P.M. Meyer, ${ }^{1}$ C.T. Marino, \\ ${ }^{3}$ M.C.A. Sucupira, ${ }^{4}$ J.J.A.A. Demarchi and ${ }^{1}$ P.H.M. Rodrigues \\ ${ }^{1}$ Department of Nutrition and Animal Production, \\ Faculty of Veterinary Medicine and Animal Science, University of Sao Paulo \\ Av. Duque de Caxias Norte, 225, Pirassununga, Brazil \\ ${ }^{2}$ Brazilian Institute of Geography and Statistics, Pirassununga, Brazil \\ ${ }^{3}$ Department of Clinical Science, Faculty of Veterinary Medicine and Animal Science, \\ University of Sao Paulo, Sao Paulo, Brazil \\ ${ }^{4}$ Sao Paulo Agency of Agribusiness Technology, Sao Paulo, Brazil
}

\begin{abstract}
Problem statement: The aim of the present study was to characterize and differentiate the effects of addition of flavomycin or monensin on ruminal fermentation and degradability as well as on total digestibility in bovine. Approach: Twelve non-pregnant and non-lactating cows (736 kg of BW) were randomly assigned to three treatments: control, flavomycin $\left(20 \mathrm{mg}\right.$ animal $\left.{ }^{-1} \mathrm{day}^{-1}\right)$ and monensin (300 mg animal ${ }^{-1}$ day $^{-1}$ ). The trial lasted 21 days. The last 10 days were used for external marker administration ( $15 \mathrm{~g}$ of chromic oxide animal ${ }^{-1} \mathrm{day}^{-1}$ ). The last 5 days of the trial were used for feces collection and evaluation of corn grain, soybean meal or sugarcane ruminal degradability and the 21 st day was used for ruminal fluid sampling. Results: Monensin increased 27.2\%, on average, propionate molar proportion at $0,4,6,8,10$ and $12 \mathrm{~h}$ after feeding, compared to control and flavomycin groups. When compared to control, flavomycin reduced the degradation rate of soybean meal CP in $31.0 \%$, decreasing the effective degradability when passage rates of 5 and $8 \% \mathrm{~h}^{-1}$ were used. Dry matter intake, $\mathrm{pH}$, total Short Chain Fatty Acids (tSCFA) or ammoniacal Nitrogen $\left(\mathrm{NH}_{3}-\mathrm{N}\right)$ concentration were not influenced by the addition of either antibiotics. Effective degradability of sugarcane NDF was not influenced by the use of either antibiotic; neither were the TDN nor the digestibility of DM, CP, EE, NFE, ADF, NDF, GE or starch of the diet. Conclusion/Recommendations: In the present study, it was possible to show the beneficial effects of monensin but not of flavomycin, on rumen fermentation.
\end{abstract}

Key words: Intake, ionophore, non-ionophore antibiotic, ruminant, short chain fatty acids

\section{INTRODUCTION}

It is widely accepted that the controlled administration of certain antibiotics can be useful for ruminants, swine and poultry (Parker and Armstrong, 1987). Since antibiotics started to be used in animal nutrition, it has been suggested that the observed improvement in performance is due to antimicrobial action on gastrointestinal microbiota (Parker and Armstrong, 1987).

In ruminants, several types of chemicals agents and antibiotics have been developed in order to manipulate the fermentative digestion and flux of nutrients from rumen (Rodrigues et al., 2001). Nowadays, most of the products used for ruminants are ionophores and in less scale, non-ionophores antibiotics. There is little information available on the effects of non-ionophores antibiotics applied in animal nutrition. These antibiotics represent a diversified group with differences in their chemical composition, antimicrobial spectrum, mode of action, molecular weight and capacity of absorption by small intestine. Avoparcin, flavomycin, tilosin and virginamicin could enhance animal growth by the modification of ruminal fermentation products (Nagaraja et al., 1997).

Flavomycin has been exclusively used as a growth promoter and its mode of action on ruminal bacterial

Corresponding Author: C.T. Marino, Department of Nutrition and Animal Production, FMVZ/USP, Av. Duque de Caxias Norte, Postcode: 13635-900, 225, Pirassununga, Brazil Tel: 55 (19) 3565-4300 
American J. Animal \& Vet. Sci., 5 (2): 76-85, 2010

\begin{tabular}{llllllrrrr}
\hline Feed & DM $(\%)$ & \multicolumn{1}{c}{ CP } & EE & Ash & NDF & ADF & Starch & $\mathrm{Ca}^{1}$ & $\mathrm{P}^{2}$ \\
\hline Sugarcane & 25.30 & 1.51 & 0.87 & 1.03 & 55.63 & 36.99 & 0.19 & 0.17 & 0.04 \\
Corn grain & 87.90 & 9.61 & 4.09 & 1.29 & 13.90 & 8.30 & 61.44 & 0.03 & 0.22 \\
Soybean meal & 89.10 & 50.05 & 1.71 & 6.24 & 11.77 & 6.57 & 0.47 & 0.32 & 0.61 \\
\hline
\end{tabular}

${ }^{1}$ Ca: Calcium, ${ }^{2} \mathrm{P}$ : Phosphorus

After incubation period, all bags were washed thoroughly by hand and dried at $55^{\circ} \mathrm{C}$ for $72 \mathrm{~h}$ for later weighing and chemical analyses as described later on the text. Results of chemical analysis of each feed are described at Table 2.

Degradability at time zero was measured by washing bags in water $\left(39^{\circ} \mathrm{C}\right)$ for $15 \mathrm{~min}$ (Cummings et al., 1983). For degradation parameters estimative, the model proposed by Orskov and McDonald (1979): $\mathrm{p}=\mathrm{a}+\mathrm{b}\left(1-\mathrm{e}^{\mathrm{ct}}\right)$ were used, where $\mathrm{p}$ is the degradation at each time, "a" is the soluble fraction; "b", the potentially degradable fraction of the insoluble fraction that would be degraded at a rate "c"; "c", the rate of degradation of fraction "b" and " $\mathrm{t}$ ", the incubation period in hours. Potential degradability $(\mathrm{Pd})$ was calculated as: $a+b$. The effective ruminal degradability (Ed) was calculated according to the mathematic model proposed by Orskov and McDonald (1979): $E d=a+[(b \times c) /(c+k)]$, where " $k$ " is the passage rate of solids by the rumen, defined as 0.02 , 0.05 and $0.08 \% \mathrm{~h}^{-1}$.

Digestibility trial consisted of 10 days from the 11th to 21 st day of each experimental period. The first five days (11-16 day) were used for marker adaptation and the last five days (17-21 day) for sample collection. Chromic oxide was used as an external marker to estimate apparent nutrient digestibility, according to Bateman (1970). For each animal, Dry Matter Intake (DMI) was measured at the last five days of each period and grab samples of feces (approximately $200 \mathrm{~g}$ ) were collected directly from the rectum at the last five days of the period. Cows received the chromic oxide, through ruminal cannulae, at $15 \mathrm{~g}$ animal ${ }^{-1} \mathrm{day}^{-1}$, twice a day (7.5 g of the marker/dose), at the moment of the meals, through absorbent paper envelopes. The chromic oxide concentration was determined by colorimetry through its reaction with $\sigma$-difenilcarbazide, according to Williams et al. (1962).

After drying at $55^{\circ} \mathrm{C}$ for $72 \mathrm{~h}$, feed and fecal samples were ground to pass a $1-\mathrm{mm}$ screen. Composite samples per cow were used to determine DM (AOAC, 1990); OM determined by ash (AOAC, 1990); CP obtained by total $\mathrm{N}$ determination using the microKjeldahl technique (AOAC, 1990); Ether Extract (EE) determined gravimetrically after extraction using petroleum ether in a Soxhlet instrument (AOAC, 1990); NDF (with heat-stable $\alpha$-amylase) and ADF according to Van Soest et al. (1991). Starch analysis was done according to Pereira and Rossi (1995), with previous extraction of soluble carbohydrates, as proposed by Hendrix (1994).

Ruminal fluid samples were collected at 21 day of each period, through ruminal cannulae with a vaccum pump at $0,2,4,6,8,10$ e $12 \mathrm{~h}$ after the morning meal. Approximately $500 \mathrm{~mL}$ of rumen fluid were collected, in each time, from three different parts of the rumen. It was returned to the pre-ventricule after the collection of the samples. Immediately after collection, $100 \mathrm{~mL}$ of rumen fluid was used for $\mathrm{pH}$ determination with a portable digital $\mathrm{pH}$ meter (HANNA instruments HI8424) calibrated with solutions of $\mathrm{pH} 4.0$ and 7.0. Then, samples were prepared and stored for further analyses of Short-Chain Fatty Acids (SCFA) and ammoniacal Nitrogen $\left(\mathrm{NH}_{3}-\mathrm{N}\right)$ concentration.

For SCFA analyses, a fraction of approximately $100 \mathrm{~mL}$ of rumen fluid was centrifuged at $2000 \times \mathrm{g}$ for $20 \mathrm{~min} ; 2 \mathrm{~mL}$ of the supernatant was added to $0.4 \mathrm{~mL}$ of formic acid and frozen at $-20^{\circ} \mathrm{C}$ for further analyses, according to Erwin et al. (1961). For this evaluation, a gas chromatography was used (model: 9001; Finnigan) equipped with a glass column of 4 feet of length and $1 / 4$ inch of diameter packed up with 80/120 Carbopack B$\mathrm{DA} / 4 \%$. For $\mathrm{NH}_{3}-\mathrm{N}$ concentration determination, $2 \mathrm{~mL}$ of the supernatant were added to $1 \mathrm{~mL}$ of $1 \mathrm{~N}$ sulphuric acid solution and the centrifuge tubes immediately frozen until the analyses by colorimetric, according method described by Kulasek (1972).

Statistical analysis: Results were analyzed by Statistical Analysis System software (SAS Institute Inc. 2001). Data of dry matter feed intake, in situ degradability and in vivo digestibility were submitted to analysis of variance (PROC GLM from SAS), which separated the treatment effect as the only cause of variation. Data of $\mathrm{pH}, \mathrm{SCFA}$ and $\mathrm{NH}_{3}-\mathrm{N}$ in ruminal fluid were analyzed as described previously, but also added the factor repeated measures in time (command REPEATED from GLM from SAS), regarding several times of sampling collection. In presence of interaction between time and treatment, analysis of variance was done inside each time through command SLICE (GLM from SAS). The effects of treatments were separated by Duncan test. Effects were declared significant at $p \leq 0.05$.

\section{RESULTS}


Values of dry matter intake are presented at Table 3. Neither of tested antibiotics altered ( $>>0.05)$ dry matter feed intake, even if data were expressed in $\mathrm{kg}$ animal $^{-1}$ day $^{-1}$, in percentage of body weight or in $\mathrm{g} \mathrm{kg}^{-1}$ of metabolic weight day ${ }^{-1}$.

Ruminal fermentation data are presented at Table 4. There was an interaction between time and treatment for variables $\mathrm{pH}(\mathrm{p}=0.0219)$, total concentration of Short Chain Fatty Acids (tSCFA) $(\mathrm{p}=0.0425)$, molar proportion of acetate $(\mathrm{p}=0.0246)$, propionate $(\mathrm{p}=$ $0.0155)$ and acetate: Proprionate ratio $(p=0.0170)$.

Although there was an interaction between time and treatment for variables $\mathrm{pH}(\mathrm{p}=0.0219)$ and tSCFA $(p=0.0425)$, there was no effect of treatment when the analyses were performed inside each time.

When the effects of treatment were evaluated inside each time, in presence of interaction, it was observed that only monensin decreased molar proportion of acetate and acetate: Propionate ratio at $0 \mathrm{~h}$ (data not shown). In relation to propionate, monensin increased ( $p>0.05)$ its molar proportion at $0,4,6,8,10$ and $12 \mathrm{~h}$, in relation to control group (Fig. 1). In relation to molar proportion of butyrate, there was an absence of treatments effect.

In general, sodium monensin increased molar proportion of propionate in $27.2 \%$ (equivalent to $5.26 \%$ units) in relation to control group, considering all measurement times. Flavomycin did not alter this variable in relation to control group.

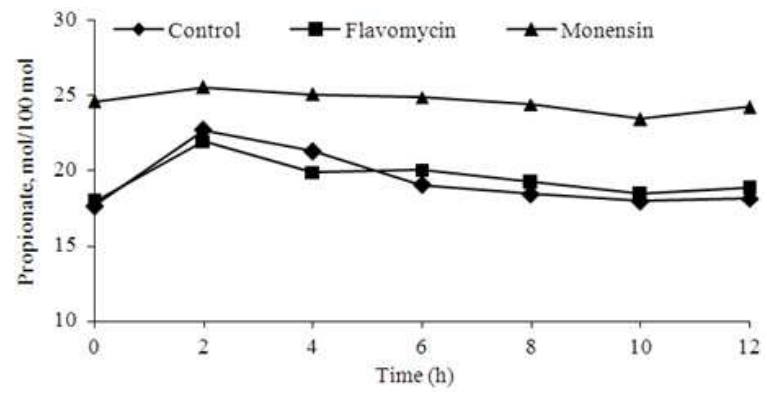

Fig. 1: Molar percentage of propionate in ruminal fluid

Table 3: Dry matter intake obtained with different treatments ${ }^{1}$

\begin{tabular}{|c|c|c|c|c|c|c|}
\hline & \multicolumn{3}{|c|}{ Treatments $^{2}$} & \multirow[b]{2}{*}{ Mean } & \multirow[b]{2}{*}{ SEM } & \multirow[b]{2}{*}{ Prob. } \\
\hline & Control & Flavomycin & Monensin & & & \\
\hline DMI & 10.56 & 8.93 & 11.33 & 10.27 & 0.57 & NS \\
\hline $\mathrm{DMI} / \mathrm{BW}$ & 1.37 & 1.25 & 1.50 & 1.37 & 0.06 & NS \\
\hline $\mathrm{DMI} / \mathrm{BW}^{0.75}$ & 72.13 & 64.55 & 78.71 & 71.80 & 3.40 & NS \\
\hline
\end{tabular}

${ }^{1}$ DMI: Dry Matter Intake (kg animal ${ }^{-1}$ day $^{-1}$ ), DMI/BW: Dry Matter

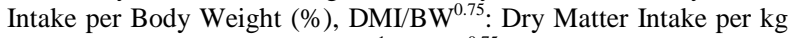
of metabolic Body Weight $\left(\mathrm{g} \mathrm{kg}^{-1}\right.$ of BW $\left.{ }^{0.75}\right)$, SEM: Standard Error of Mean; Prob: Statistical Probability; NS: Non-Significant; ${ }^{2}$ : Rows with different letters differ by Duncan test (5\%)
No tested treatment altered ruminal degradability parameters of sugarcane NDF (Table 5).

For corn grain starch (Table 5), monensin and flavomycin differed $(\mathrm{p}<0.05)$ in effective degradability, although none of them differed from control group. Differences were $9.6 \%, 19.1 \%$ and $24.3 \%$ for passage rates of 2,5 and $8 \% \mathrm{~h}^{-1}$, taking as basis the increase caused by monensin in relation to the group treated with flavomycin.

Table 4: Ruminal fermentation pattern obtained with treatments ${ }^{1}$

\begin{tabular}{|c|c|c|c|c|c|c|}
\hline & \multicolumn{3}{|c|}{ Treatments $^{2}$} & \multirow[b]{2}{*}{ SEM } & \multicolumn{2}{|c|}{ Probability } \\
\hline & Control & Flavomycin & Monensin & & Treat. & Treat*Time \\
\hline$\overline{\mathrm{pH}}$ & 6.32 & 6.23 & 6.27 & 0.03 & NS & 0.0219 \\
\hline tSCFA & 100.53 & 102.71 & 99.89 & 1.59 & NS & 0.0425 \\
\hline $\mathrm{C}_{2}$ & 69.05 & 69.59 & 64.36 & 0.53 & NS & 0.0246 \\
\hline $\mathrm{C}_{3}$ & $19.33^{\mathrm{b}}$ & $19.47^{\mathrm{b}}$ & $24.59^{\mathrm{a}}$ & 0.41 & 0.0390 & 0.0155 \\
\hline $\mathrm{C}_{4}$ & 11.62 & 10.93 & 11.05 & 0.27 & NS & NS \\
\hline $\mathrm{C}_{2} / \mathrm{C}_{3}$ & 3.66 & 3.75 & 2.65 & 0.10 & 0.0850 & 0.0170 \\
\hline $\mathrm{NH}_{3}-\mathrm{N}$ & 13.88 & 13.16 & 14.37 & 0.43 & NS & NS \\
\hline
\end{tabular}

${ }^{1}$ tSCFA: Total Short Chain Fatty Acids concentration (mM); $\mathrm{C}_{2}$ : Acetate $(\mathrm{mol} / 100 \mathrm{~mol}) ; \mathrm{C}_{3}$ : Propionate $(\mathrm{mol} / 100 \mathrm{~mol}) ; \mathrm{C}_{4}$ : Butyrate $(\mathrm{mol} / 100 \mathrm{~mol}) ; \mathrm{C}_{2} / \mathrm{C}_{3}$ : Acetate: Propionate ratio; $\mathrm{NH}_{3}-\mathrm{N}$ : Ammoniacal Nitrogen $\left(\mathrm{mg} \mathrm{dL}^{-1}\right)$; SEM: Standard Error of Mean; Treat: Probability for treatment effect; Treat*Time: Probability for treatment and time interaction effect; NS: non-significant; ${ }^{2}$ : Rows with different letters differ by Duncan test $(5 \%)$

Table 5: In situ degradability of sugarcane NDF, corn grain starch and soybean meal $\mathrm{CP}$ obtained with treatments ${ }^{1}$ Treatments $^{2}$

\begin{tabular}{|c|c|c|c|c|c|}
\hline & Control & Flavomycin & Monensin & SEM & Prob. \\
\hline \multicolumn{6}{|c|}{ Sugarcane NDF } \\
\hline $\mathrm{a}$ & 7.5900 & 7.5600 & 8.5500 & 0.300 & NS \\
\hline $\mathrm{b}$ & 47.0800 & 51.0500 & 42.2900 & 1.990 & NS \\
\hline $\mathrm{c}$ & 0.0245 & 0.0143 & 0.0183 & 0.002 & NS \\
\hline $\mathrm{Ed} 2$ & 32.9200 & 28.2400 & 27.5000 & 1.710 & NS \\
\hline Ed5 & 22.6900 & 18.8300 & 19.3000 & 1.170 & NS \\
\hline Ed8 & 18.3600 & 15.3300 & 16.0800 & 0.880 & NS \\
\hline $\mathrm{Pd}$ & 54.6600 & 58.6200 & 50.8400 & 1.830 & NS \\
\hline \multicolumn{6}{|c|}{ Corn grain starch } \\
\hline $\mathrm{a}$ & 3.4600 & 4.4300 & 5.5200 & 0.620 & NS \\
\hline $\mathrm{b}$ & 99.7600 & 100.4300 & 96.6600 & 0.700 & NS \\
\hline $\mathrm{c}$ & 0.0549 & 0.0472 & 0.0715 & 0.005 & NS \\
\hline $\mathrm{Ed} 2$ & $76.0700^{\mathrm{ab}}$ & $73.5500^{\mathrm{b}}$ & $80.5800^{\mathrm{a}}$ & 1.300 & 0.0642 \\
\hline Ed5 & $55.2000^{\mathrm{ab}}$ & $51.9900^{\mathrm{b}}$ & $61.9000^{\mathrm{a}}$ & 1.820 & 0.0582 \\
\hline $\mathrm{Ed} 8$ & $43.6900^{\mathrm{ab}}$ & $40.8100^{b}$ & $50.7300^{\mathrm{a}}$ & 1.800 & 0.0499 \\
\hline $\mathrm{Pd}$ & $103.2200^{\mathrm{ab}}$ & $104.8600^{\mathrm{a}}$ & $102.1800^{\mathrm{b}}$ & 0.530 & NS \\
\hline \multicolumn{6}{|c|}{ Soybean meal CP } \\
\hline $\mathrm{a}$ & 14.2000 & 12.5400 & 16.3000 & 0.710 & 0.0798 \\
\hline $\mathrm{b}$ & $86.8500^{\mathrm{b}}$ & $91.2500^{\mathrm{a}}$ & $83.3800^{\mathrm{b}}$ & 1.180 & 0.0063 \\
\hline $\mathrm{c}$ & $0.1087^{\mathrm{a}}$ & $0.0750^{\mathrm{b}}$ & $0.1278^{\mathrm{a}}$ & 0.008 & 0.0069 \\
\hline $\mathrm{Ed} 2$ & 87.4500 & 83.4500 & 88.3300 & 1.000 & NS \\
\hline Ed5 & $73.5500^{\mathrm{ab}}$ & $66.0400^{\mathrm{b}}$ & $76.1300^{\mathrm{a}}$ & 1.730 & 0.0296 \\
\hline Ed8 & $64.1000^{\mathrm{ab}}$ & $55.6300^{\mathrm{b}}$ & $67.4800^{\mathrm{a}}$ & 1.950 & 0.0296 \\
\hline Pd & $101.0400^{\mathrm{b}}$ & $103.7900^{\mathrm{a}}$ & $99.6700^{\mathrm{b}}$ & 0.640 & 0.0080 \\
\hline
\end{tabular}
Degradability for passage rates of $0.02,0.05$ and 0.08 ; Pd: Potential degradability; SEM: Standard Error of Mean, Prob: Statistical probability; NS: Non-significant; ${ }^{2}$ : Rows with different letters differ by Duncan test $(5 \%)$ 
Table 6: Apparent digestibility of diet DM and its nutrients obtained with treatments (DM \%)

\begin{tabular}{|c|c|c|c|c|c|}
\hline \multirow[b]{2}{*}{ Nutrients ${ }^{1}$} & \multicolumn{3}{|c|}{ Treatments $^{2}$} & \multirow[b]{2}{*}{ SEM } & \multirow[b]{2}{*}{ Prob. } \\
\hline & Control & Flavomycin & Monensin & & \\
\hline$\overline{\mathrm{DM}}$ & 67.69 & 70.49 & 64.17 & 2.51 & NS \\
\hline $\mathrm{CP}$ & 69.23 & 71.33 & 69.00 & 2.21 & NS \\
\hline $\mathrm{EE}$ & 69.65 & 69.79 & 64.89 & 3.09 & NS \\
\hline NFE & 76.08 & 78.63 & 71.54 & 2.41 & NS \\
\hline $\mathrm{NDF}$ & 40.70 & 53.74 & 33.91 & 5.51 & NS \\
\hline $\mathrm{ADF}$ & 57.90 & 66.31 & 50.06 & 4.69 & NS \\
\hline Starch & 95.51 & 97.81 & 91.21 & 2.22 & NS \\
\hline TDN & 68.54 & 71.04 & 64.77 & 2.46 & NS \\
\hline GE & 72.68 & 79.03 & 67.79 & 3.22 & NS \\
\hline
\end{tabular}

${ }^{1}$ Nutrients: DM: Dry Matter; CP: Crude Protein; EE: Ether Extract; NFE: Nitrogen-Free Extractive; NDF: Neutral Detergent Fiber; ADF: Acid Detergent Fiber; TDN: Total Digestible Nutrients; GE: Gross Energy; ${ }^{2}$ : Rows with different letters differ by Duncan test $(5 \%)$

For CP of soybean meal, the treatment with flavomycin decreased $(\mathrm{p}<0.05)$ degradation rate (parameter c) in 31.0 and $41.3 \%$, increased $(p<0.05)$ the potentially degradable fraction (parameter $b$ ) in 5.1 and $9.4 \%$ and the potential degradability $(\mathrm{a}+\mathrm{b})$ in 2.7 and $4.1 \%$, in relation to control group and to the group treated with monensin, respectively. Flavomycin also resulted in lower $(\mathrm{p}<0.05)$ effective degradabilities of $\mathrm{CP}$ of soybean meal, in relation to monensin, but not in relation to control. The decrease of effective degradability of soybean meal $\mathrm{CP}$ in relation to monensin varied between 13.25 and $17.56 \%$ (10.09 and $11.85 \%$ units), considering passage rates of 5 and $8 \% \mathrm{~h}^{-1}$, respectively.

Data from dry matter digestibility and its nutrients are presented at Table 6. No effect of antibiotics on $\mathrm{CP}$, EE, NDF, ADF, NFE, starch, GE digestibility or TDN was shown.

\section{DISCUSSION}

In general, dry matter feed intake, which on average was $1.37 \%$ of body weight, independently from treatment, was lower than expected when it was considered this animal category. This can be due to the low quality of sugarcane fiber, high body condition of animals at the beginning of the experiment or both factors.

Neither of tested antibiotics altered dry matter feed intake, which corroborated with Flachowsky and Richter (1991) that did not observe effects on dry matter intake when flavomycin was added ( 0 or $30 \mathrm{mg}$ animal $^{-1}$ day $^{-1}$ ) to heifer's diets. The same was observed by Zinn et al. (1994), when monensin was added to steers diets containing 10 or $20 \%$ of forage.

However, in a trial carried out by Alert et al. (1993), the addition of $50 \mathrm{mg}$ animal $^{-1}$ day $^{-1}$ of flavomycin to the diets of feedlot young bulls resulted in higher feed intake in the treated group when compared to control. This finding contrasted with the concept that antibiotics generally decrease feed intake, improving feed conversion (Stock and Mader, 1984), where this decrease in feed intake was more evident in animals fed high-grain diets than high forage diets (Schelling, 1984).

There was no effect of treatment was observed for ruminal $\mathrm{pH}$ when the analyses were performed inside each time of sampling. These results agreed with Rodrigues et al. (2004) who did not observe effect of monensin administration on total concentration of SCFA. However, Mbanzamihigo et al. (1995) studied monensin infusion in the rumen of cannulated sheep and observed decrease in total concentration of SCFA and increase in ruminal $\mathrm{pH}$. Still related to ruminal $\mathrm{pH}$, Rodrigues et al. (2004) studied the effects of monensin and different proportions forage/concentrate in diet on ruminal fermentation in cattle and verified an increase in this variable, but only in the most concentrate-based diet. These data opposed those presented by Zinn et al. (1994), who observed that with an increase in the forage proportion of diet, monensin increased ruminal $\mathrm{pH}$. So diversified results obtained with this ionophore were also reported by Rodrigues et al. (2004), who affirmed that the response to this product depends on experimental conditions, such as type of diet, product dose and others.

Differently from what was observed in the present study, Edwards et al. (2005) added $20 \mathrm{mg} \mathrm{day}^{-1}$ of flavomycin to a TMR for sheep and observed that total concentration of SCFA (acetate, propionate, butyrate, valerate and isobutyrate) decreased. A decrease in total concentration of SCFA was also observed by other authors with this antibiotic (Alert et al., 1993; Marounek et al., 1998; McKain et al., 2000), although they did not observe any change in ruminal $\mathrm{pH}$. Murray et al. (1990) compared the effect of flavomycin in two different diets and verified an increase in ruminal $\mathrm{pH}$ in the diet that contained alfalfa plus lupine. Also, total concentration of SCFA increased, but only when this product was added to the diets based on wheat and fishmeal. Therefore, results obtained with flavomycin seem to be as variable as those obtained with monensin, at least for these variables.

In general, sodium monensin increased molar proportion of propionate in $27.2 \%$ (equivalent to $5.26 \%$ units) in relation to control group, considering all measurement times. Flavomycin did not alter this variable in relation to control group. This report is in agreement with an experiment carried out by Ramanzin et al. (1997) who fed diets with 50 or $30 \%$ of 
concentrate to dairy cows and observed greater effects of monensin on molar proportion of propionate, also this effect was more pronounced in the most concentrate-based diet $(26.7 \%$ versus $8.9 \%$, respectively). Garcia-Lopez et al. (1996) worked with different proportions of concentrate $(0,50$ and 90\%) in an in vitro experiment and noticed that monensin increased the molar proportion of propionate in 17.1 and $47.9 \%$ for diets that contained 0 and $50 \%$ of concentrate, respectively, but did not alter this variable when the diet contained $90 \%$ of concentrate. These last authors cited that the low dose used could be the cause of lack of effect in concentrate-based diet.

When monensin was administered in a diet composed of corn silage and concentrate, the rate of propionate production increased in $65 \%$ (Rogers and Davis, 1982) and, when administered in a diet composed of wheat straw and concentrate, the increase was of 44\% (Prange et al., 1978). According to Chen and Wolin (1979), these effects of monensin are due to its inhibitory effect on formate and hydrogen-producing bacteria and stimulatory effect on succinate and propionate-producing bacteria. This phenomenon is doubly advantageous in metabolic terms for the animal, as ruminal production of propionate is energetically more efficient than acetate (Chalupa, 1977; Hungate, 1966).

In relation to flavomycin, the present data are compatible to the absence of results on SCFA observed by Marounek et al. (1998) and Alert et al. (1993).

Flavomycin or monensin, in the doses used in this experiment, did not cause any response on ruminal concentration of $\mathrm{NH}_{3}-\mathrm{N}$. Normally, in experiments with monensin, a reduction in production or concentration of this metabolite was observed (Rodrigues et al., 2004), due to an inhibition caused on a small population of Gram-positive bacteria with high proteolytic activity and desamination (Chen and Russell, 1989; Russell et al., 1988).

Differently from what was observed in the present trial, Murray et al. (1990) reported that flavomycin decreased ammonia ruminal concentration in the diet that contained wheat plus fishmeal. This decrease was about $14 \%$ in sheep that received wheat and concentrate (Edwards et al., 2002). Although this decrease in ammonia ruminal concentration can indicate an increase in bacterial protein synthesis or a decrease in desamination, Van Der Merwe et al. (2001), cited that, in the case of flavomycin, what occurs is a restriction of desamination, caused by a direct suppression of some bacteria with high activity of ammonia production in rumen (Edwards et al., 2005).

No tested treatment altered ruminal degradability parameters of sugarcane NDF These results contrasted with those presented by Vagnoni et al. (1995), who observed decrease in NDF degradability of diet with sodium monensin utilization in cattle. This decrease was higher in diets containing wheat straw without ammonia treatment when compared to treated straw. The absence of effects on fiber degradability is compatible with degradability data found in the present experiment, as will be forward discussed.

Increases on effective degradability of starch as observed in the present study can be considered useful, once an increase in degradation rate of corn grain starch can result in higher availability of nutrients in rumen and consequently to the animal. Potential degradabilities over $100 \%$, as seen in the present experiment, are commonly observed when a non-linear statistic procedure is used in degradation curves of some feed.

The results observed for $\mathrm{CP}$ degradability of soybean meal can be considered valuable in certain conditions, since they can provide to animal better utilization of protein from diet reaching the small intestine. The results from the present trial corroborated with those observed by Edwards et al. (2005) who reported that flavomycin can lead to an increase of quantity of aminoacids available for the animal through a decrease in ruminal proteolysis, increasing the dietetic protein available for intestinal absorption.

No tested antibiotics altered dry matter digestibility. Similar results were obtained by Thornton and Owens (1981) and Zinn et al. (1994) where monensin did not affect DM or OM digestibility respectively, independently on diet characteristics. But, several authors reported an increase in DM and OM digestibility with ionophores antibiotics use (Duff et al., 1995; Horton et al., 1980; Richter and Flachowski, 1990). The present findings also agreed with Flachowsky and Richter (1991) who worked with cattle and reported that flavomycin did not influence OM apparent digestibility or TDN, as well as, ruminal fermentation parameters. However, Alert et al. (1993) mentioned, in an experiment with young bulls, an increase in OM, CF and NFE with flavomycin supplementation.

It was expected that a decrease in the degradation rate of protein fraction, observed in group that received flavomycin and discussed before, could result in lower $\mathrm{NH}_{3}-\mathrm{N}$ productions and, therefore, lower losses of nitrogen in rumen. Consequently, an increase in the digestibility of this fraction was expected. Bergen and Bates (1984) reported similar finding for monensin. These authors observed that this product, despite frequently decreased protein degradation in rumen, caused variable impact on DM 
or CP digestibility, based on basal diet used. According to Bateman et al. (2004), if an increase in microbial efficiency occurs due to monensin addition associated with an increase in aminoacids flux to small intestine, an improvement in protein status of the animal could occur. Another point to mention is that, in the present trial, the apparent digestibility was evaluated not the true digestibility. This could have contributed for the lack of antibiotic effect on digestibility.

The tested antibiotics did not alter NDF or ADF digestibility. The results of the present experiment agreed with De Schrijver et al. (1991) who did not observe any effect of flavomycin on DM, NDF or NFE digestibility in castrated sheep, fed with a mixed of sugar beet pulp plus concentrate and flavomycin. Therefore, the lack of effect of this antibiotic on NDF digestibility could be valid for feed that had high digestible fiber, such as sugar beet pulp (De Schrijver et al., 1991), but also, low digestible fiber, such as sugarcane that was used in this experiment.

The effect of monensin on fiber digestibility is contradictory in literature. It could be observed positive or negative effects. The effects of ionophores on fiber digestibility are explained in part by an increase in DM retention time in rumen (Ellis et al., 1983), lower voluntary feed intake (Rogers and Davis, 1982), improvement in ruminal conditions (Branine and Galyean, 1990) or by increase in rumination stimulus (Knowlton et al., 1996).

Although ionophores cause low to moderate improvement in feed digestibility (Schelling, 1984), these conditions are not defined at the present moment and may suffer influence of several factors such as feed intake, rumen filling, passage rate and others. Also, it is worth to mention that the present study used nonpregnant dry cows, animals that have lower feed intake and consequently lower passage rates of feed in gastrointestinal tract. It is possible that these experimental conditions help to explain the lack of results observed in this study.

\section{CONCLUSION}

In conditions of concentrate-based diets with sugarcane as the single forage, it was possible to show the beneficial effects of monensin but not of flavomycin, on rumen fermentation. As flavomycin decreased crude protein ruminal degradability, it can improve the utilization of this nutrient.

\section{ACKNOWLEDGEMENT}

This study was supported by Sao Palo Research Foundation, FAPESP, Brazil. The researchers thank FAPESP for providing financial support. Moreover, E. Lazaro and G. Botteon for animal care and A. Castro, G. Godoy, S. Robassini and I. Ramos for assistance with laboratory analysis.

\section{REFERENCES}

Alert, H.J., S. Poppe and M. Lohner, 1993. The effect of flavomycin on the fattening performance of bulls. Arch. Tierernahr., 43: 371-380. DOI: 10.1080/17450399309386051

AOAC., 1990. Official Methods of Analysis. 15th Edn., Association of Official Analytical Chemists, Inc., Washington DC., USA., ISBN: 10: 0935584420, pp: 1850.

Bateman, H.J., C.C. Williams, D.T. Gantt, Y.H. Chung and A.E. Beem et al., 2004. Effects of zinc and sodium monensin on ruminal degradation of lysine-HCL and liquid 2-hydroxy-4methylthiobutanoic acid. J. Anim. Sci., 87: 2571-2577. PMID: 15328281

Bateman, J. 1970. Nutricion Animal-Manual de Metodos Analiticos. 1st Edn., Herrero Hermanos, Mexico, ISBN: 0-03-05365-8, pp: 405-449.

Bergen, W.G. and D.B. Bates, 1984. Ionophores: Their effect on production efficiency and mode of action. J. Anim. Sci., 58: 1465-1483. PMID: 6378864

Branine, M.E. and M.L. Galyean, 1990. Influence of grain and monensin supplementation on ruminal fermentation, intake, digesta kinetics and incidence and severity of frothy bloat in steers grazing winter wheat pasture. J. Anim. Sci., 68: 1139-1150. PMID: 2332388

Chalupa, W., 1977. Manipulating rumen fermentation. J. Anim. Sci., 45: 585-599. http://jas.fass.org/cgi/reprint/45/3/585

Chen, G. and J.B. Russell, 1989. More monensinsensitive, ammonia-producing bacteria from the rumen. Applied Environ. Microbiol., 55: 1052-1057. PMID: 2757371

Chen, G.J. and J.B. Russell, 1991. Effect of monensin and protonophore on protein degradation, peptide accumulation and deamination by mixed ruminal microorganisms in vitro. J. Anim. Sci., 69: 2196-2203. PMID: 1829725.

Chen, M. and M.J. Wolin, 1979. Effect of monensin and lasalocid-sodium on the growth of methanogenic and rumen saccharolytic bacteria. Applied Environ. Microbiol., 38: 72-77. PMID: 16345418 
Cummings, K.A., J.E. Nocek, C.E. Polan and J.H. Herbein, 1983. Nitrogen degradability and microbial protein synthesis in calves fed diets of varying degradability by the bag technique. J. Dairy Sci., 66: 2356-2364. DOI: 10.3168/JDS.S00220302(83)82093-1

De Schrijver, R., D. Freumat and B. Claes, 1991. Flavomycin effects on performance of beef bulls and nutrient digestibility in wethers. Dtsch. Tierarztl. Wochenschr., 98: 47-50. PMID: 2026115

Dennis, S.M., T.G. Nagaraja and E.E. Bartley, 1981. Effects of lasolacid or monensin on lactate producing or using rumen bacteria. J. Anim. Sci., 52: 418-426. PMID: 7275867

Duff, G.C., M.L. Galyean and M.E. Branine, 1995. Effects of adaptation to lasalocid, monensin or a daily rotation of lasalocid and monensin on in vitro fermentation of a $90 \%$ concentrate diet. Can. J. Anim. Sci., 75: 129-134. http://article.pubs.nrccnrc.gc.ca/RPAS/rpv?hm=HInit\&calyLang=eng\&j ournal=cjas \&volume=75\&afpf=cjas95-017.pdf

Duffield, T.F., D. Sandals, K.E. Leslie, K. Lissemore and B.W. McBride et al., 1998. Effect of prepartum administration of monensin in a controlled-release capsule on postpartum energy indicators in lactating dairy cows. J. Dairy Sci., 81: 2354-2361. PMID: 9785226

Edwards, J.E., N.R. McEwan, N. McKain, N. Walker and R.J. Wallace, 2005. Influence of flavomycin on ruminal fermentation and microbial populations in sheep. Microbiology, 151: 717-725. PMID: 15758218

Edwards, J.E., R.J. Wallace and N.R. McEwan, 2002. The growth promoting mode of action of flavomycin in ruminants. Reprod. Nutr. Dev., 42: S55-S55.

Ellis, W.C., G.W. Horn, D. Delaney and K.R. Pond, 1983. Effects of ionophores on grazed forage utilization and their economic value for cattle on wheat pasture. Proceedings of the National Wheat Pasture Symposium, (NWPS'83), Oklahoma Agriculture Experiment Station, Oklahoma State University, Stillwater OK., pp: 343-355.

Erwin, E.S., G.J. Marco and E.M. Emery, 1961. Volatile fatty acid analyses of blood and rumen fluid by gas chromatography. J. Dairy Sci., 44: 1768-1771.

Febel, H., M. Szelenyl, J. Jecsai and B. Juhasz,1988. Effect of salinomycin, flavomycin and avoparcin on some physiological traits of growing lambs, with particular respect to rumen fermentation. Acta Vet. Hung., 36: 69-80. PMID: 3264455
Flachowsky, G. and G.H. Richter, 1991. Effect of flavomycin on the apparent digestibility of crude nutrients in wethers, parameters of rumen fermentation in cattle and feed intake and weight gain of heifers. Arch. Tierernahr., 41: 303-310. PMID: 1859272

Funk, M.A., M.L. Galyean and T.T. Ross, 1986. Potassium and lasalocid effects on performance and digestion in lambs. J. Anim. Sci., 63: 685-691. PMID: 3759698

Garcia-Lopez, P.M., L. Kung Jr. and J.M. Odom, 1996. In vitro inhibition of microbial methane production by 9,10-Anthraquinone. J. Anim. Sci., 74: 22762284. PMID: 8880433

Hendrix, D.L., 1994. Rapid extraction and analyses of nonstructural carbohydrates in plant tissues. Crop Sci., 33: 1306-1311.

Horton, G.M.J., K.A. Bassendowski and E.H. Keeler, 1980. Digestion and metabolism in lambs and steers fed monensin with different levels of barley. J. Anim. Sci., 50: 997-1008. http://jas.fass.org/cgi/content/abstract/50/6/997

Hungate, R.E., 1966. The Rumen and its Microbes. 1st Ed., Academic Press, New York, USA., pp: 206.

Knowlton, K.F., M.S. Allen and P.S. Erickson, 1996. Lasalocid and particle size of corn for dairy cows in early lactation. 2. Effect on ruminal measurements and feeding behavior. J. Dairy Sci., 79: 565-574. PMID: 8744221

Kulasek, G., 1972. A micromethod for determining urea in blood plasma, whole blood and blood corpuscles with the use of urease and phenol reagent. Pol. Arch. Med. Wewn., 15: 801-810. PMID: 4663270

Marounek, M., D. Duskove and V.Skrivanova, 1998. Effect of non-ionophore feed antibiotics on in vitro fermentation in the ovine rumen and rabbit caecum. J. Agric. Sci., 130: 115-118. DOI: $10.1017 / \mathrm{S} 0021859697005042$

Mbanzamihigo, L., C.J. Van Nevel and D.I. Demeyer, 1995. Adaptation of rumen fermentation to monensin. Reprod. Nutr. Dev., 35: 353-365. PMID: 7546227

McGuffey, R.K., L.F. Richardson and J.I.D. Wilkinson, 2001. Ionophores for dairy cattle: Current status and future outlook. J. Dairy Sci., 84: 194-203. http://jds.fass.org/cgi/reprint/84/e-suppl/E194

McKain, N., J. Edwards, R.J. Wallace, S. Edwards and L. Bruce et al., 2000. Effects of flavomycin in the gastrointestinal tract of sheep. Reprod. Nutr. Dev., 40: 222. 
Mehrez, A.Z. and E.R. Orskov, 1977. A study of artificial fibre bag technique for determining the dig estibility of feeds in the rumen. J. Agric. Sci., 88: 645-650. DOI: 10.1017/S0021859600037321

Murray, P.J., J.B. Rowe and E.M. Aitchison, 1990. The influence of protein quality on the effect of flavomycin on wool growth, liveweight change and rumen fermentation in sheep. Aust. J. Agric. Res., 41: 987-993.

Nagaraja, T.G., C.J. Newbold, C.J. Van Nevel and D.I. Demeyer, 1997. Manipulation of Ruminal Fermentation. In: The Rumen Microbial Ecosystem, Hobson, P.N. and C.S. Stewart (Eds.). Blackie, New York, USA., pp: 523-632. ISBN: 978-0-7514-0366-4.

NRC., 2001. Nutritional Requirements of Dairy Cattle. 7th Edn., National Academy Press, Washington, DC., USA. ISBN: 0-309-06997-1.

Orskov, E.R. and I. McDonald, 1979. The estimation of protein degradability in the rumen from incubation measurements weighted according to rate of passage. J. Agric. Sci., 92: 499-503. DOI: 10.1017/S0021859600063048

Ovchinnikov, Y.A., 1979. Physico-chemical basis of ion transport through biological membranes: Ionophores and ion channels. Eur. J. Biochem., 94: 321-336.

http://onlinelibrary.wiley.com/doi/10.1111/j.14321033.1979.tb12898.x/pdf

Parker, D.S. and D.G. Armstrong, 1987. Antibiotic feed additives and livestock production. Proc. Nutr. Soc., 46: 415-421. PMID: 3324100

Pereira, J.R.A. and P. Rossi Jr., 1995. Practical Manual of Nutritional Evaluation of Feedstuffs. 1st Edn., FEALQ, Piracicaba, ISBN: 0-05-043256-6, pp: 25.

Phipps, R.H., J.I. Wilkinson, L.J. Jonker, M. Torrant, A.K. Jones and A. Hodge, 2000. Effect of monensin on milk production of Holstein-Friesian dairy cows. J. Dairy Sci., 83: 2789-2794. PMID: 11132848

Prange, R.W., C.L. Davis and J.H. Clark, 1978. Propionate production in the rumen of Holstein steers fed either a control or a monensin supplemented diet. J. Anim. Sci., 46: 1120-1124. http://jas.fass.org/cgi/reprint/46/4/1120

Ramanzin, M., L. Bailoni, S. Schiavon and G. Bittante, 1997. Effect of monensin on milk production and efficiency of dairy cows fed two diets differing in forage to concentrate ratios. J. Dairy Sci., 80: 1136-1142. PMID: 9201584

Richter, G.H. and G. Flachowski, 1990. Influence of lasalocid on apparent digestibility, rumen fermentation, fattening and slaughtering performance of bulls. Arch. Anim. Nutr., 40: 981-990. http://www.informaworld.com/smpp/ftinterface $\sim \mathrm{db}$ $=$ all $\sim$ content $=\mathrm{a} 914641557 \sim$ fulltext $=713240930$
Rodrigues, P.H.M., W.R.S. Mattos, P.M. Meyer, C.S. Lucci and L. Melotti, 2004. Effects of monensin level and roughage/concentrate ratio on ruminal fermentation in bovines. J. Anim. Feed Sci., 13: 195-198. http://psjc.icm.edu.pl/psjc/cgibin/getdoc.cgi?AAAA011457

Rodrigues, P.H.M., W.R.S Mattos, L. Melotti and R.R. Rodrigues, 2001. Monensina e digestibilidade aparente em ovinos alimentados com diferentes proporcoes de volumoso/concentrado. Sci. Agric., 58: 449-455.

http://www.scielo.br/pdf/sa/v58n3/a02v58n3.pdf

Rogers, J.A. and C.L. Davis, 1982. Rumen volatile fatty acid production and nutrient utilization in steers fed a diet supplemented with sodium bicarbonate and monensin. J. Dairy Sci., 65: 944-952. PMID: 6286742

Russell, J.B., H.J. Strobel and G.J. Chen, 1988. Enrichment and isolation of a ruminal bacterium with a very high specific activity of ammonia production. Applied Environ. Microbiol., 54: 872-877. PMID: 3377500

SAS., 2001. Statistical analysis systems user's guide. SAS Institute Inc.

Schelling, G.T., 1984. Monensin mode of action in the rumen. J. Anim. Sci., 58: 1518-1527. http://jas.fass.org/cgi/reprint/58/6/1518

Stock, R. and T. Mader, 1984. Feed additives for beef cattle. University of Nebraska.

Thornton, J.H. and F.N. Owens, 1981. Monensin supplementation and in vivo methane production by steers. J. Anim. Sci., 52: 628-634. PMID: 6267003

Vagnoni, D.B., W.M. Craig, R.N.Gates, W.E. Wyatt and L.L. Southern, 1995. Monensin and ammoniation or urea supplementation of bermudagrass hay diets for steers. J. Anim. Sci., 73: 1793-1802. PMID: 7673074

Van Der Merwe, B.J., T.J. Dugmore and K.P. Walsh, 2001. The effect of flavophospholipol $\left(\right.$ Flavomycin $^{\circledR}$ ) on milk production and milk urea nitrogen concentrations of grazing dairy cows. S. Afr. J. Anim. Sci., 31: 101-105. http://ajol.info/index.php/sajas/article/viewFile/383 $5 / 11773$

Van Heijenoort, J., 2001. Formation of the glycan chains in the synthesis of bacteria peptidoglycan. Glycobiology, 11: 25R-36R. http://glycob.oxfordjournals.org/cgi/reprint/11/3/25R

Van Soest, P.J., J.B. Robertson and B.A. Lewis, 1991. Methods for dietary fiber, neutral detergent fiber and nonstarch polysaccharides in relation to animal nutrition. J. Dairy Sci., 74: 3583-3597. http://jds.fass.org/cgi/reprint/74/10/3583.pdf 
Zinn, R.A., A. Plascencia and R. Barajas, 1994. Interaction of forage level and monensin in diets for feedlot cattle on growth performance and digestive function. J. Anim. Sci., 72: 2209-2215. PMID: 8002439
Williams, C.H., D.J. David and O. Iismaa, 1962. The determination of chromic oxide in faeces samples by atomic absorption spectrophotometry. J. Agric. Sci., $\quad$ 59: $\quad 381-385 . \quad$ DOI: 10.1017/S002185960001546X 